\title{
Hydrological cycle
}

\author{
Gonçalves, HC. ${ }^{\mathrm{a}}$, Mercante, MA. ${ }^{\mathrm{b} *}$ and Santos, ET. ${ }^{\mathrm{c} *}$ \\ ${ }^{a}$ Agência Nacional de Águas, SPS, Área 5, Quadra 3, Bloco B, CEP 70610-200, Brasília, DF, Brazil \\ 'Programa de Pós-graduação em Meio Ambiente e Desenvolvimento Regional, Universidade Anhanguera - Uniderp, \\ Rua Alexandre Herculano, 1400, Jardim Veraneio, CEP 79037-280, Campo Grande, MS, Brazil \\ ${ }^{\mathrm{c} U n i v e r s i d a d e}$ Anhanguera - Uniderp, Rua Ceará, 333, Miguel Couto, \\ CEP 79003-010, Campo Grande, MS, Brazil \\ *e-mail: humberto.goncalves@ana.gov.br, mercante@terra.com.br,eva_tsantos@yahoo.com.br \\ Received October 14, 2010 - Accepted December 13, 2010 - Distributed April 30, 2011
}

(With 5 figures)

\begin{abstract}
The Pantanal hydrological cycle holds an important meaning in the Alto Paraguay Basin, comprising two areas with considerably diverse conditions regarding natural and water resources: the Plateau and the Plains. From the perspective of the ecosystem function, the hydrological flow in the relationship between plateau and plains is important for the creation of reproductive and feeding niches for the regional biodiversity. In general, river declivity in the plateau is $0.6 \mathrm{~m} / \mathrm{km}$ while declivity on the plains varies from 0.1 to $0.3 \mathrm{~m} / \mathrm{km}$. The environment in the plains is characteristically seasonal and is home to an exuberant and abundant diversity of species, including some animals threatened with extinction. When the flat surface meets the plains there is a diminished water flow on the riverbeds and, during the rainy season the rivers overflow their banks, flooding the lowlands. Average annual precipitation in the Basin is 1,396 mm, ranging from $800 \mathrm{~mm}$ to $1,600 \mathrm{~mm}$, and the heaviest rainfall occurs in the plateau region. The low drainage capacity of the rivers and lakes that shape the Pantanal, coupled with the climate in the region, produce very high evaporation: approximately $60 \%$ of all the waters coming from the plateau are lost through evaporation. The Alto Paraguay Basin, including the Pantanal, while boasting an abundant availability of water resources, also has some spots with water scarcity in some sub-basins, at different times of the year. Climate conditions alone are not enough to explain the differences observed in the Paraguay River regime and some of its tributaries. The complexity of the hydrologic regime of the Paraguay River is due to the low declivity of the lands that comprise the Mato Grosso plains and plateau (50 to $30 \mathrm{~cm} / \mathrm{km}$ from east to west and 3 to $1.5 \mathrm{~cm} / \mathrm{km}$ from north to south) as well as the area's dimension, which remains periodically flooded with a large volume of water.
\end{abstract}

Keywords: Pantanal of Brazil, water resources, hydrologic regime.

\section{Ciclo hidrológico}

\section{Resumo}

O ciclo hidrológico do Pantanal guarda um significado importante na bacia do Alto Paraguai, a qual compreende duas áreas em condições consideravelmente diversas no que se refere aos recursos hídricos e naturais, o planalto e a planície. Sob o enfoque de função ecossistêmica, o fluxo hidrológico na relação planalto-planície é importante para a criação de nichos reprodutivos e alimentares para a biodiversidade regional. Em geral, a declividade dos rios no planalto é de $0,6 \mathrm{~m} / \mathrm{km}$ enquanto que a declividade na planície é de 0,1 a $0,3 \mathrm{~m} / \mathrm{km}$, e o ambiente na planície é caracteristicamente sazonal e mantém uma diversidade de espécies exuberantes em abundância, inclusive de animais ameaçados de extinção. Ao encontrar a planície, a superfície plana faz diminuir o fluxo de água no leito dos rios e, na época de chuva, os rios transbordam seus leitos, inundando a planície. A precipitação média anual da bacia é de $1.396 \mathrm{~mm}$, variando entre $800 \mathrm{~mm}$ e $1.600 \mathrm{~mm}$, e as maiores chuvas são observadas na região do planalto. A baixa capacidade de drenagem dos rios e lagos que formam o Pantanal e o clima da região fazem com que, aproximadamente, 60\% de todas as águas provenientes do planalto sejam perdidas por evaporação. A bacia do Alto Paraguai, incluindo o Pantanal, embora tenha abundante disponibilidade de recursos hídricos, apresenta situações de escassez em determinadas sub-bacias e em determinadas épocas do ano. As condições climáticas por si só não são suficientes para explicar as diferenças que são observadas no regime do rio Paraguai e de alguns de seus afluentes. A complexidade do regime hidrológico do rio Paraguai está relacionada à baixa declividade dos terrenos que integram as planícies e pantanais mato-grossenses (de 50 a $30 \mathrm{~cm} / \mathrm{km}$ no sentido leste-oeste e de 3 a $1,5 \mathrm{~cm} / \mathrm{km}$ de norte para o sul) e também à extensão da área que permanece periodicamente inundada com grande volume de água.

Palavras-chave: Pantanal do Brasil, recursos hídricos, regime hidrológico. 


\section{Introduction}

The Alto Paraguay Basin, covering roughly $600,000 \mathrm{sq} \mathrm{km}$, has $362,376 \mathrm{~km}$ in Brazil, comprising $4.3 \%$ of the national territory, that basin holds considerable importance in the strategic context of water resources management for Brazil, Bolivia and Paraguay, which share it not only for its dimensions, but for being home to the Pantanal, one of the largest stretches of flooded areas in the planet, with $147,574 \mathrm{sq} \mathrm{km}$, constituting a link between the Cerrados in Brazil, and the Chaco in Bolivia and Paraguay.

The drastically seasonal environment of the Pantanal boasts a diversity of exuberant and abundant species, including endangered species. Aspects of flooding and drainage, topography and nutrients strongly influence the landscapes and the supplies of feeding and reproductive niches for the native fauna.

The present study, which adopts an ecosystem function focus, aims to demonstrate that the hydrologic flow of the Pantanal is related to the geographic position of the Upper Paraguay Basin, with its plateau and plain compartments that interact to form reproductive and feeding niches for the biodiversity of the region.

\section{Procedures Adopted}

Data were extracted from integrated management action programmes for the Pantanal and Upper Paraguay Basin (ANA, 2008), in which the combined strategies aim to demonstrate that the Pantanal is important for the management of water resources in Brazil and the neighbouring countries that share this basin - Bolivia and Paraguay.

In order to correlate water resources with the rich biodiversity of the Pantanal, data were inserted containing ecosystem approaches (Alho and Gonçalves, 2005).

\section{Pantanal and the Ecosystem Context}

The Pantanal is a lowland area subject to periodical flooding, which is nationally and internationally recognised for the exuberance of its biodiversity, as a humid area of utmost importance in the globe. It is part of the Upper Paraguay River Basin (BAP) and is formed by the Paraguay River and, in Brazil, by its tributaries, especially the ones located on the left bank.

The river Paraguay is one of the major tributaries of the Prata River Basin, the second largest river basin in South America, outsized only by the Amazon Basin, expanding through a total area of 3,100,000 sq km, draining almost $20 \%$ of the South American continent. Of all the rivers that form the Prata River Basin, the Paraguay River is the one that runs deepest into the centre of the continent. Before its confluence with the Paraná river, it runs an extension of $2,612 \mathrm{~km}, 1,683 \mathrm{~km}$ of which is within Brazilian territory, with some sections shared with Bolivia and Paraguay.

The Alto Paraguay Basin comprises two areas with considerably diverse conditions regarding natural and water resources: the Plateau and the Plains (Figure 1). The Plateau is located on the north and east of Alto Paraguay hydrographic basin. It is a relatively high altitude area, with datum levels above $200 \mathrm{~m}$, sometimes reaching $1,400 \mathrm{~m}$, located in the basin's eastern region, almost entirely within Brazilian territory, where drainage is well defined and converging. The Pantanal, one of the main biomes in South America, is located in the lowlands, also comprising flood-prone areas in Bolivia and Paraguay.

The Pantanal is a lowland area, located in the centre of the basin, where the rivers flood the plains and feed an intricate drainage system comprised of extensive lakes, diverging water bodies and seasonal drainage and flooded areas. The Pantanal region possesses datum levels ranging from $80 \mathrm{~m}$ to $150 \mathrm{~m}$ and was formed by the sinkage of a large area, which occurred simultaneously with the emergence of the Andes Mountain Range (Silva, 1984). The datum level of $200 \mathrm{~m}$ altitude corresponds, approximately, to the boundaries of the Pantanal lowlands, and the steep slopes, mountains and the Plateau's tablelands.

Finally, there is the Chaco, located west of the Brazilian border, which is a lowland area, where precipitation is below 1,000 mm per year, with large areas where river flow forms swamps or lakes, which rest without a defined drainage system.

While the fountainheads of the rivers that form the Pantanal have their origins in the highlands, with a predominant cerrado biome, and typical environmental, economic and social context of the cerrado, the flooded lowlands below, called Pantanal, have their own unique characteristics of seasonably flood-prone areas.

It must be noted, for instance, that roughly the same amount of water that comes from local precipitation in the Pantanal is lost through evapotranspiration. Thus, the regime of flooding and draining, which is fundamental for the functions of the natural system, relies fundamentally on the cerrado portion - the fountainheads on the highlands, a vital fraction in the BAP for the Pantanal.

From the perspective of ecosystem function, the crucial element for the functioning of the Pantanal system in the relationship between plateau and lowlands, is the hydrologic flow that creates feeding and reproductive niches for the regional biodiversity. Because of those characteristics, the Cerrados/Pantanal system is considered one of the biodiversity and water resources hot-spots in the planet, for its importance and for the degree of exposure to environmental threats.

The lowlands are formed by the tributaries on the left bank of the Paraguay River, within Brazilian territory, with its western border touching the territory of Bolivia to the north and Paraguay to the south (Figure 2).

The plateau's fountainheads feed different basins, in accordance with slope direction. The waters from the highlands at the extreme northern portion of Alto Paraguay Basin (Parecis and Cuiabá) flow toward the Amazon Basin on the northernmost side, and to BAP through the downward slope running towards south; the eastern slopes (Bodoquena, Maracaju and São Jerônimo) drain through 


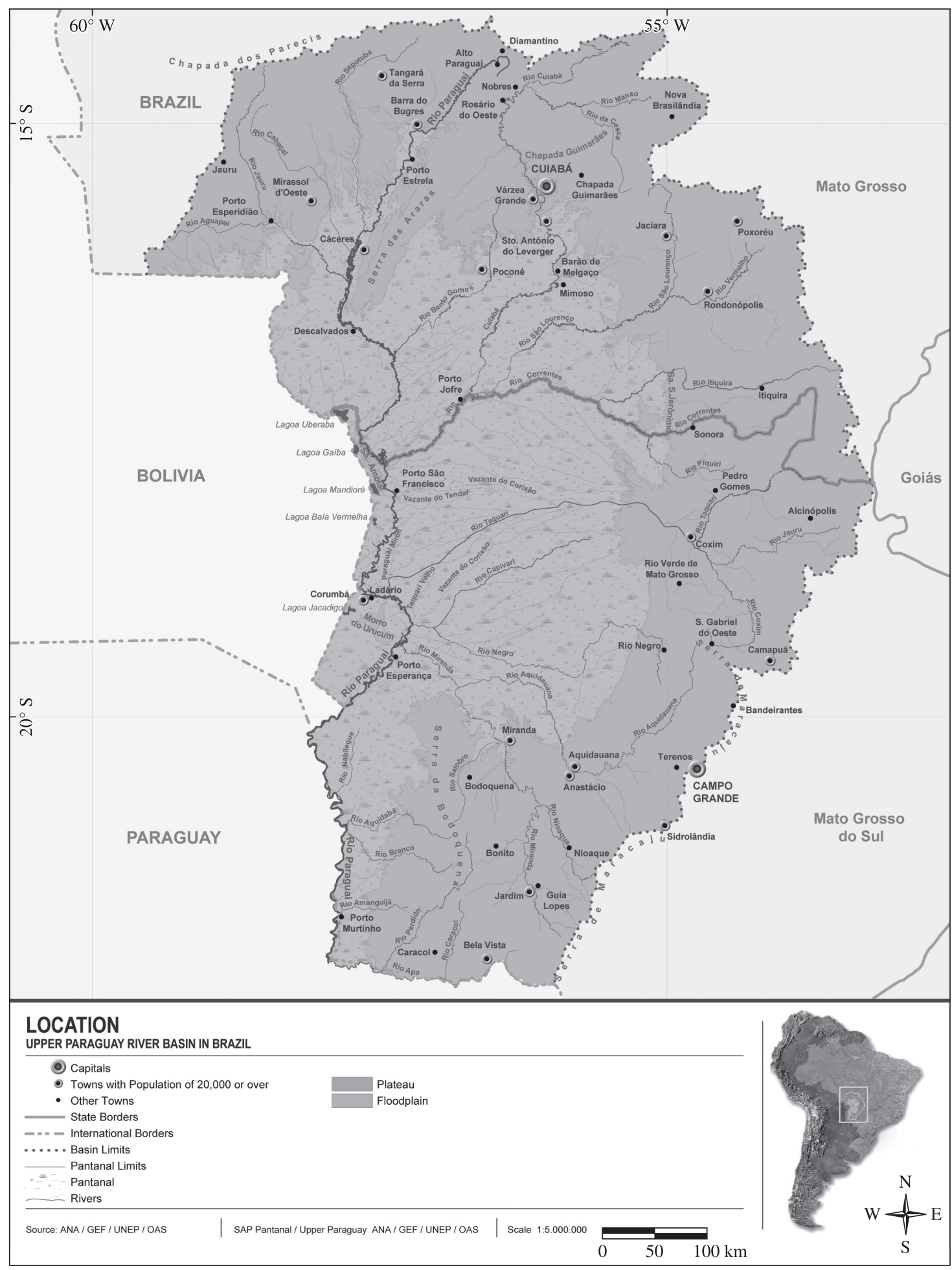

Figure 1. Location of the Pantanal/Upper Paraguay River in Brazil (ANA, 2004). 


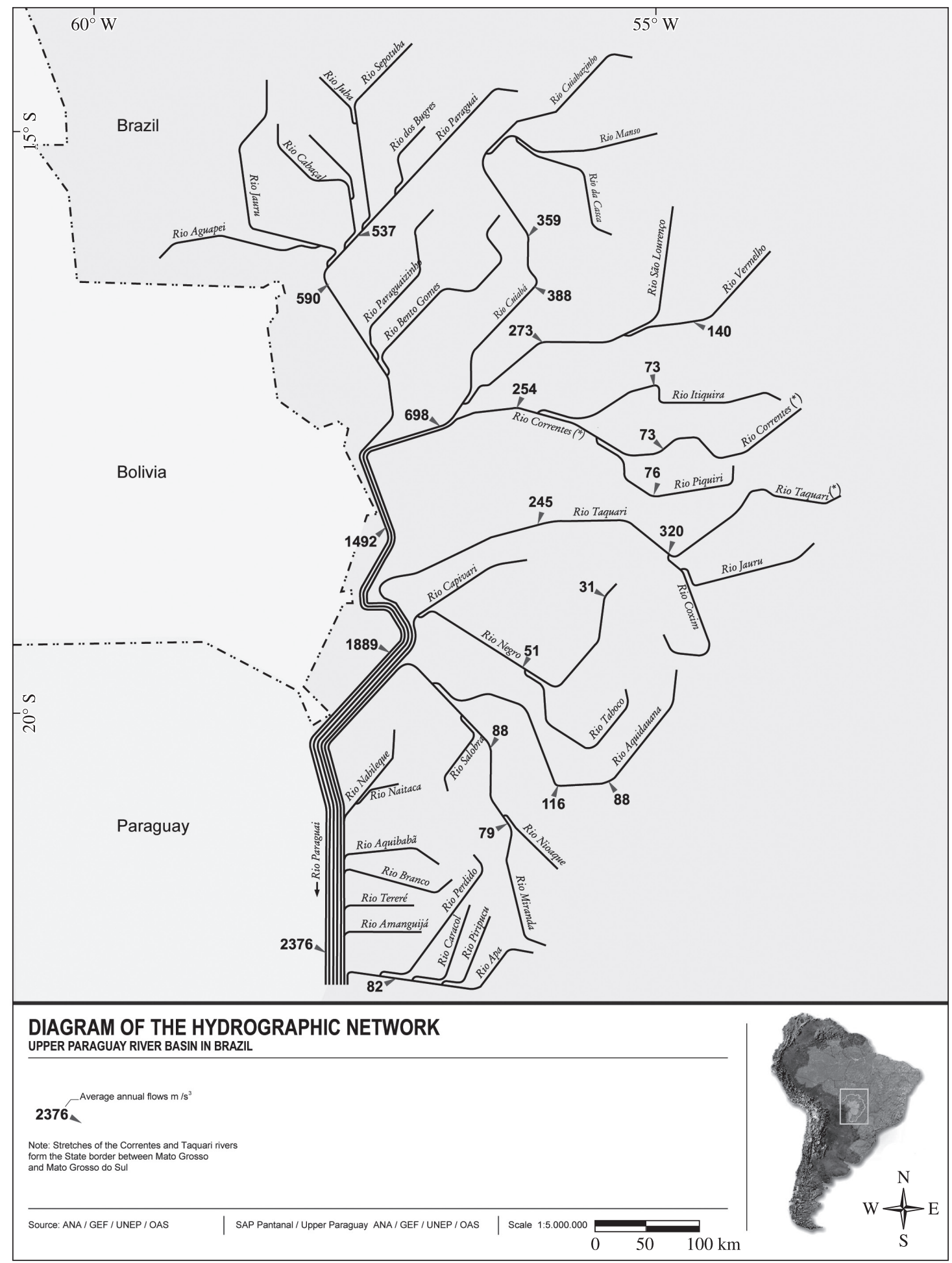

Figure 2. Upper Paraguay River Basin in Brazil - Diagram $\mathrm{f}$ the hydrographic network (ANA, 2004). 
the eastern declivity towards Araguaia and Paraná rivers, and, through the western declivity they flow into the Alto Paraguay Basin.

The main rivers running down from the highlands into the plains are: from north to south, Paraguay, Bento Gomes, Cuiabá, São Lourenço - Itiquira, Taquari, Negro, Aquidauana - Miranda, Nabileque and Apa rivers.

When the flat surfaces meet the plains, they slow down the water flow in the riverbeds and during the rainy season, the rivers overflow their banks, thus flooding the lowlands.

In general, river declivity in the plateau is $0.6 \mathrm{~m} / \mathrm{km}$ while declivity on the plains varies from 0.1 to $0.3 \mathrm{~m} / \mathrm{km}$. The depressions get filled with water, forming the baías, which are channels linking flooded valleys, shaping the channels (corixos); and shallower depressions interconnect the flooded areas, forming the drainage ditches.

The Basin does not boast a wide climate variation and may be wholly classified as a tropical humid climate. Average annual temperatures vary between $22.5^{\circ} \mathrm{C}$ and $26.5^{\circ} \mathrm{C}$. The hottest month is November (with an average temperature of $27^{\circ} \mathrm{C}$ ) and the coolest is July (with an average temperature of $21^{\circ} \mathrm{C}$ ).

Average annual precipitation in the Basin is $1,396 \mathrm{~mm}$, ranging from $800 \mathrm{~mm}$ to $1,600 \mathrm{~mm}$, and the heaviest rainfall occurs in the Plateau region. The rainy season is from October through April and the other months make up the dry season. Average annual evaporation is $1,239 \mathrm{~mm}$, with peaks in August, when higher rates of insolation are observed (Figure 3).

The average water flow in the Basin was $2,464 \mathrm{~m}^{3} / \mathrm{s}$, at the confluence with the Apa river, in the period 1939-2002 (Figure 4). The Pantanal acts as a great reservoir, retaining the largest share of the waters originated from the Plateau, thus regularising the flow from Paraguay River during up to five months, between inflows and outflows. In Cáceres, the greatest average flow happens in March, at the end of the rainy season; in Porto São Francisco, it occurs in April and May; in Porto Murtinho the flow is greater in June and July, entirely outside the rainy season. In the Plateau, the specific flows reach 13/18 1/s/ sq km and, in the Pantanal, in general, they are less than $0.5 \mathrm{l} / \mathrm{s} / \mathrm{sq} \mathrm{km}$. Table 1 shows the average monthly and annual flow in the Pantanal and Alto Paraguay Basin (ANA, 2004).

On the northern portion of the Pantanal, the relative contribution of the tributaries coming down from the plateau accounts for $72 \%$ of the flows running into the Paraguay River. For the southern Pantanal, it corresponds to $28 \%$.

The northern portion of the Pantanal receives contributions from: Alto Paraguay - 27\%; Alto and Médio Cuiabá - 20\%; São Lourenço - 14\%; CorrentesItiquira-Piquiri - $11 \%$.

The contributions in the southern portion of the Pantanal come from: Alto Taquari - 16\%; Negro - 3\%; Alto Aquidauana - 5\% and Alto Miranda - 4\%. It should be noted that the Basin's declivity in the plateau is $30 \mathrm{~cm} / \mathrm{km}$ on average, and in the Pantanal it is $3-5 \mathrm{~cm} / \mathrm{km}$, running from east to west and 1.5 to $3 \mathrm{~cm} / \mathrm{km}$ in the north-south direction, towards the Paraguay River.
In the Pantanal, the flooding area of the alluvial fans has an average expanse of $50,000 \mathrm{~km}^{2}$ (Figure 5). Ladário is the reference fluviometric station in the Brazilian Pantanal. The station has been monitored by the Brazilian Navy since 1900. When the maximum annual level in Ladário reaches or exceeds $4 \mathrm{~m}$, it is considered that there is flooding in the Pantanal; When the level varies between 4 and $5 \mathrm{~m}$, the flood is light; between 5 and $6 \mathrm{~m}$, it is considered normal and above $6 \mathrm{~m}$, it is deemed a severe flood. In years of very intense rainfall, such as $1988(6.64 \mathrm{~m}$, the greatest historical mark) and 1995 (6.56 m, third greatest mark in the century), the Paraguay River, in the Pantanal, overflows its banks by flooding and expands to a width of $20 \mathrm{~km}$. Land submersion depth in the Pantanal ranges from $0.5 \mathrm{~m}$ to $1.5 \mathrm{~m}$ in average. Submersion duration varies greatly. In some areas the floods may last up to six months. The floods confined in the sub-basins do not have a direct influence on the Pantanal floods.

The low drainage capacity of the rivers and lakes that form the Pantanal, coupled with the region's climate, produce intense evaporation. Approximately $60 \%$ of all the waters originated from the Plateau are lost through evaporation.

The current knowledge of the conditions of the Alto Paraguay Basin, in terms of surface water availability and demand, indicates that the greatest demand in the entire Pantanal/Alto Paraguay Basin is destined to animal drinking. The greatest demands for irrigation are located in areas of the Miranda, Itiquira and Correntes rivers sub-basins. The greatest urban and industrial demands are located in the Alto and Médio Cuiabá river basins. Those demands are relatively small $(3.5 \%)$ as compared to the average water availability. It should be noted, however, that urban and rural water supply in the Pantanal/Alto Paraguay Basin makes widespread use of water collection from shallow and deep wells.

The Alto Paraguay Basin, including Pantanal, while boasting an abundant availability of water resources, also presents some conditions of scarcity in some sub-basins and different periods of the year, due to the hydric balance or the observed use.

The rivers in the region have the capacity to convey the average discharges, but during the flood season, they inundate extensive areas of lowlands, forming temporary lakes that take up a total area of roughly 100,000 sq km. In early May, the water level starts to slowly go down, and the area becomes characteristically swampy. When the lowlands dry up, the soils are covered with a thin layer of nutrients that fertilise the grasslands that feed a herd estimated in three million heads.

As for underground waters, the basin's largest portion is made up of porous aquifers associated with non consolidated sediments that cover ancient rocky substratum. The underground aquifers are located at an average depth of $50 \mathrm{~m}$ and their discharge exceeds an average of $30,000 \mathrm{~L} / \mathrm{h}$. there is an abundance of underground water in the Pantanal, but there is some evidence of potential forthcoming problems with water quality, in terms of salinity and the presence of heavy metals. In general terms, the quality of water 


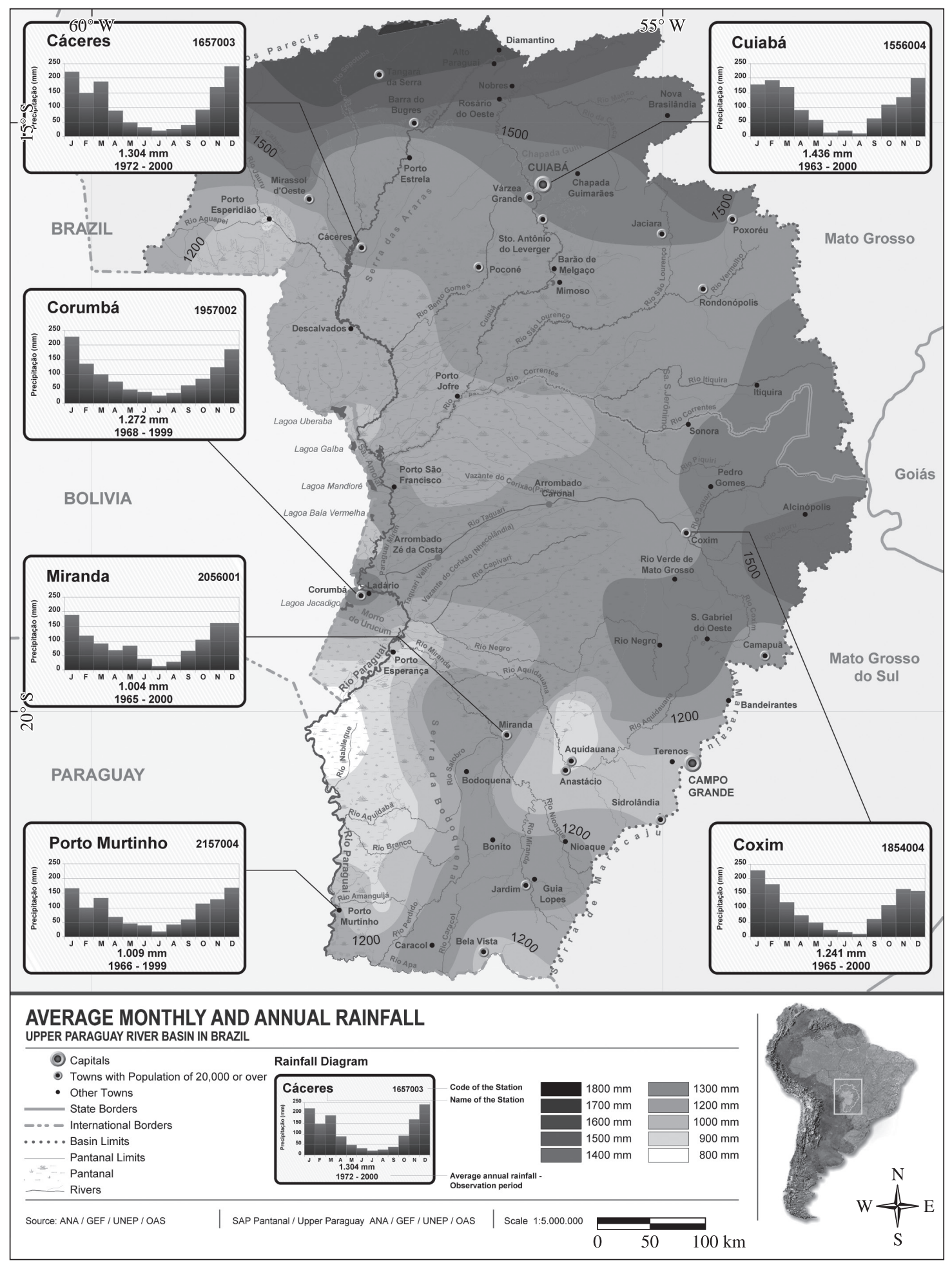

Figure 3. Upper Paraguay River Basin in Brazil - Average monthly and annual rainfall (ANA, 2004). 


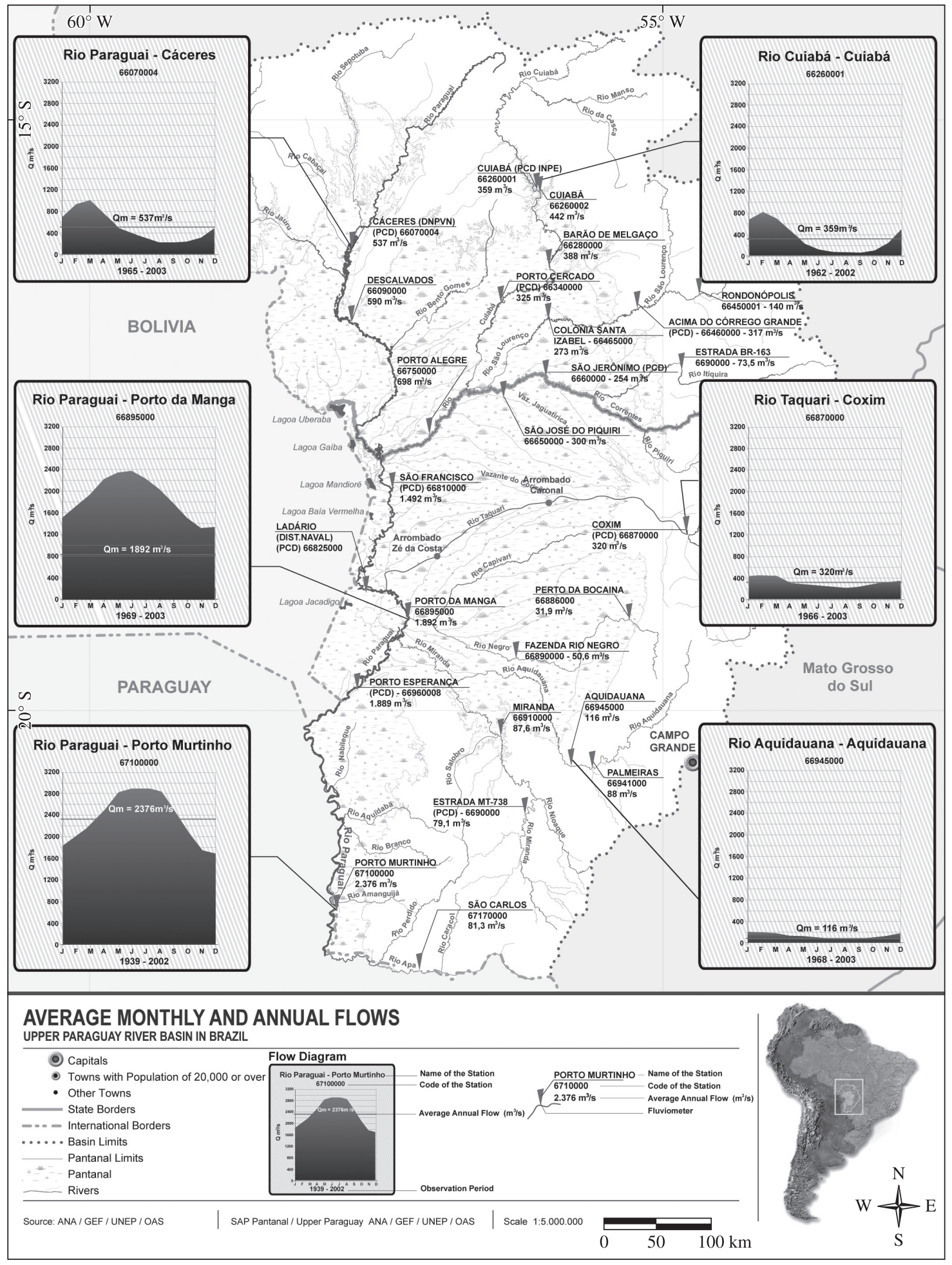

Figure 4. Upper Paraguay River Basin in Brazil - Average Monthly and Annual Flows (ANA, 2004). 


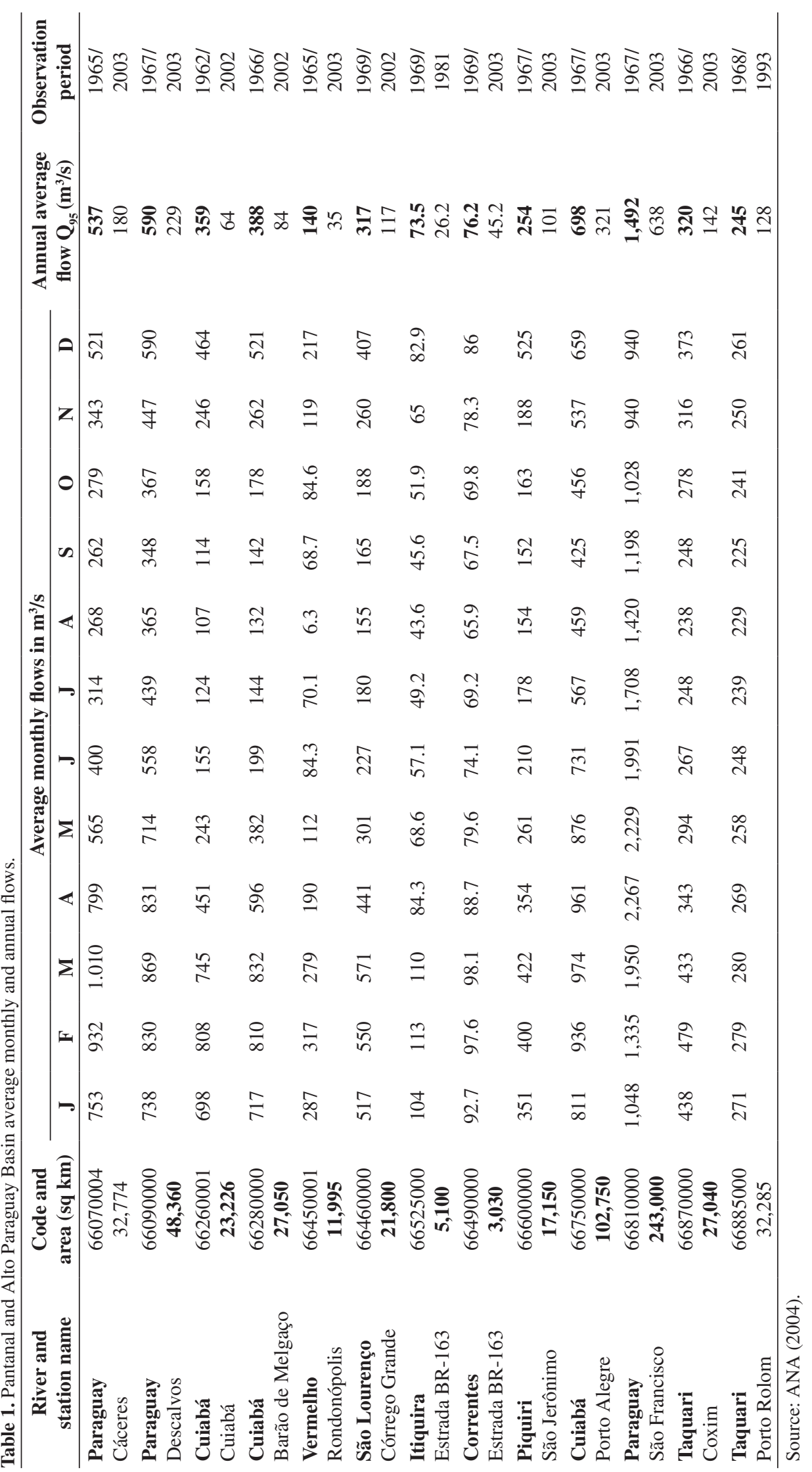




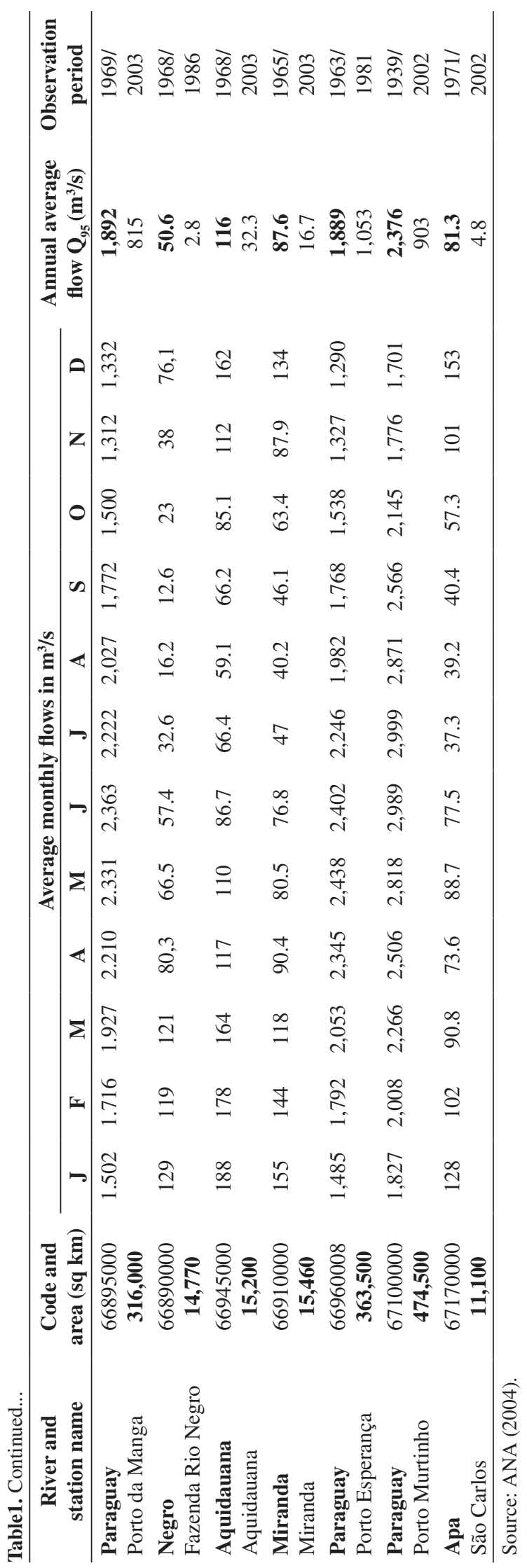




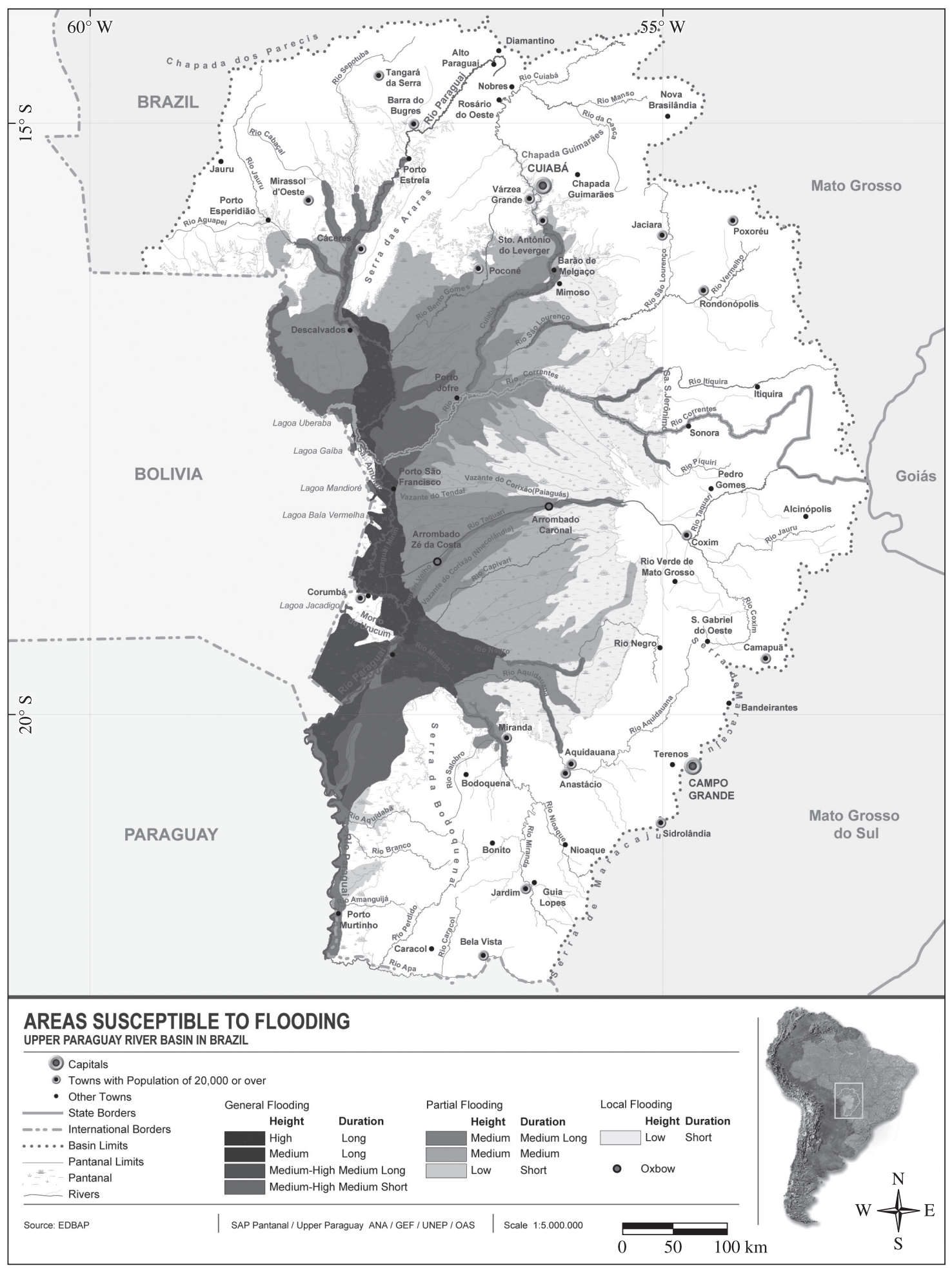

Figure 5. Upper Paraguay River Basin in Brazil - Areas susceptible to flooding (ANA, 2004). 
in the plateau may be considered good, although water availability is somewhat more restricted to some areas.

The Pantanal regulates river discharge through periodical flooding. It hoards the waters and also stimulates water loss through evapotranspiration and soil infiltration. The river sediments are retained during the passage of river waters through the Pantanal with the consequent transformation of solutions and biogeochemical elements that are important for the biodiversity in the region.

\section{The Natural System and its Functioning}

\subsection{Dynamics of inundation}

Hydrology in the Pantanal is irregular: even being seasonal, the flood periods vary throughout the plains, due to the volume of water flows running into the lowlands and to the smooth and flat declivity of the terrain. The flood periods may be delayed after rainfall on the riverheads in the plateau, due to the slow passage of the waters through the flooded plains. A great portion of the Pantanal is flooded by river discharge, which overflows their banks when they reach the Pantanal, but in some specific spots, the local rainfall may also produce shallow floods. During the period of high water levels, the water flows move slowly through the Pantanal, interconnecting the rivers with the depressions, through canals and drainage ditches, filling up the flood-prone areas. The water level at the Paraguay River channel in Ladário is close to $6 \mathrm{~m}$ and approximately $2 \mathrm{~m}$ in the portion where the river overflows in the plains.

The Paraguay River runs from north to south along the western part of Pantanal, and receives water from its tributaries, particularly the ones located on the left bank. River declivity in the Pantanal is $2.5 \mathrm{~cm}$ per km (EDIBAP, 1979) and there is the presence of large lakes along the river, with close hydrologic relationship with the Paraguay River, which has a sinuous shape in the Pantanal portion. Those lakes are: to the south of Corumbá, Jacadigo Lake; to the north of Corumbá, we find Baía Vermelha, Lagoa Mandioré, Lagoa Guaíba and Lagoa Uberaba. Past the city of Cáceres, the river declivity ranges from $6.3 \mathrm{~cm}$ km-1 to $1 \mathrm{~cm} \mathrm{km-1} \mathrm{near} \mathrm{the} \mathrm{Apa} \mathrm{River} \mathrm{(Carvalho,} \mathrm{1986).}$

After receiving a strong influx of water in its riverheads, the Paraguay River supplies water to the flood-prone areas of the Pantanal, but the flood wave may be delayed by four to five months until it reaches the southern portion of Pantanal. Thus, the changes in water levels show that there is a delay of approximately four months before the water level passes through the Pantanal, from north to south, and reaches the city of Corumbá. During this period, when water levels reach their peak in Corumbá, the dry season is already underway in the northern Pantanal (Hamilton et al., 1996).

In the city of Corumbá, the Paraguay River annual discharge is $1,260 \mathrm{~m}^{3} / \mathrm{s}-1$ (cubic metres per second) when the river accounts for $80 \%$ of the flow in the region (EDIBAP, 1979). While the National Water Agency (ANA, 2004) estimates that the Paraguay River discharge in Porto
Murtinho is 2,376 m³ $/ \mathrm{s}-1$, other estimates show a discharge of 2,500 m³ $/ \mathrm{s}-1$ in Corumbá (Hamilton et al., 1997).

Hydrologic data show that there are marked differences between the northern and southern portions of Pantanal: the flood regime and flood fluctuation is greater in the north. However, the physical and chemical conditions of the waters in the southern portion of the Pantanal are more stable than in the northern portion, since the north is drier in the dry season. Peak discharge from the tributaries occurs earlier than the Paraguay River discharge, and the subsequent elevation of the Paraguay River waters block the flow of its tributaries (Hamilton et al., 1996). As mentioned before, the flood peaks produced by the Paraguay River discharge in the south occurs four months later than rainfall peaks in the riverheads, so the floods are mainly caused by river overflow and not by rainfall (Hamilton et al., 1996).

The largest flood-prone areas are located along the Paraguay River, between Porto Conceição and Porto Murtinho, reaching depths of $1 \mathrm{~m}$ to $1.5 \mathrm{~m}$. Those floods may last for up to six months. In the other areas of the Pantanal, submersion of the flood-prone areas has a depth of roughly half a metre and the flood duration varies from region to region. In the area of Paraguay and Jauru rivers, it lasts approximately 70 days; in Cuiabá, AquidauanaMiranda, it lasts roughly 40 days and in Taquari and São Lourenço rivers, the duration is about 30 days, according to data from PCBAP (1997a). In the portion of Pantanal that receives water from the Negro and Taboco rivers, the flood may reach $1.2 \mathrm{~m}$ and last up to 90 days. The floodprone area measures approximately $300 \mathrm{~km}$ by $400 \mathrm{~km}$, and may reach a total area of approximately $137,000 \mathrm{sq} \mathrm{km}$, mostly within Brazilian territory and some small sections in Bolivia and Paraguay (Hamilton et al., 1996, 1997).

Long-range studies show that the flood pattern in the Pantanal varies from February, in the north, through June, in the south, as a result of the drainage delay in the region (Hamilton et al., 1996, 1997). During nine years of observations, an area of 131,000 sq km was flooded, between 1979 and 1987. The estimates for total monthly flooded areas vary between 11,000 and 110,000 sq km.

\subsection{Seasonality and yearly cycles}

There are very pronounced seasonal floods in the alluviums of Taquari, with peaks occurring in February. This demonstrates the inter-annual variability in maximum and minimal levels of the flooded areas (Hamilton et al., 1998). The water influx from the river Taquari has its peak one or two months after rainfall peak in the region. Thus, the floods may be a result of that influx and also of local rainfall. After March, the water deficit is explained by the evapotranspiration of the flooded area.

The areas where the Taquari river fountainheads are located have an erosive potential, but are protected by natural plant cover. With the advent of deforestation, the erosion became more severe, producing the so-called arrombados of the Taquari River in the Pantanal. Arrombados are fissures in the river bank caused by intense siltage in the 
riverbed. Such alteration has provoked changes in the seasonal flooding regime and transformed areas that were only periodically flooded in areas of permanent inundation, currently estimated to occupy an area of $11,000 \mathrm{sq} \mathrm{km}$ (ANA, 2004).

In northern Pantanal, the floods occur between March and April, while in the south they take place from July to August. Between November and March there is intense water loss due to evapotranspiration. The heaviest rainfall occurs from October through March. The river flows $\left(\mathrm{m}^{3} \mathrm{~s}^{-1}\right)$ have their influx from January through April, with peaks in March and the discharges occur from April through October, with peaks in June-July, measured in Porto Esperança, on the Paraguay River (Hamilton et al., 1997).

Maximum seasonal flood in the region occurs between February and April, and declines, with peak dry weather between October and December. Besides the annual floods, there are variations in longer periods of time, with no defined pattern. Such floods are influenced by several factors, in both the macro and micro scales. The river level variations rely fundamentally on the precipitation characteristics each year. The river level is an indicator of two important variables: drainage and size of the river canal, including the adjacent area.

The slow flow of waters in the Pantanal is a determinant factor for the loss of sediments in suspension, and contributes to the drop of dissolved oxygen levels and decreased $\mathrm{pH}$.

Statistical treatment of data from the hydrometric station in Ladário, in the period 1900-1996, identified seven categories of floods, in an attempt to establish a methodology for a system of flood alert (Adamoli, 1996). During that period, the critical level of four metres of river depth was exceeded in 61 out of the 97 years of observation recorded in Ladário. In some years, there were severe floods, when the water level exceeded 6 metres (in the years 1905, 1913, 1920, 1921, 1980, 1981, 1983, 1986, 1989, and 1995). In contrast, there were dry years, with river levels below two metres (1910, 1911, 1915, 1938, 1939, $1941,1944,1948$ and from 1964 to 1973$)$. In the period 1961 to 1973 there was diminished precipitation, and the extent of variations in the Paraguay River also declined, as detected by different methods (Sá et al., 1998). From then on, there was a considerably more humid period, from 1974 to 1996.

Such hydrologic seasonability, with an annual hydraulic pattern, is ecologically decisive for wildlife survival in Pantanal.

\section{Hydrologic Behaviour}

The data obtained from Ladário measurements are fundamental if one needs to get a full grasp of the hydrologic behaviour of the Paraguay River in the BAP section. That fluviometric station possesses a vast series of levels. Moreover, the station controls approximately $81 \%$ of the average water outflow from the Brazilian territory (ANA, 2008).
The Paraguay River's fountainheads are located in the complex of the Parecis Mountain Range, close to the city of Diamantino in the state of Mato Grosso. It drains the Pantanal, together with its tributaries. In the BAP, Paraguay River expands and forms a damming zone, and becomes the main tributary of BAP, that comprises two distinct regions: the Plateau and Pantanal.

Valverde (1972) considers three factors as preponderant for the regularity of the Paraguay river's fluvial regime: periodic annual rainfall with maximum regularity, falling on the basin, especially on the upstream tributaries; extensive flooded and damming zone in the Pantanal, which feeds the system during the dry season and smooth slopes in the longitudinal section and a great uniformity in the gradient, from São Luis de Cáceres up until the mouth of the Paraguay River.

Those considerations are evidence of the conjugated action of several factors in the hydrologic behaviour of the water bodies.

The upstream course of the Paraguay River in the Plateau corresponds to the fountainhead area, or mountains and depressions, and because of that, the river has rapids and a declivity equivalent to $75 \mathrm{~cm} / \mathrm{km}$. One may observe that the riverheads have a quick response to precipitation, with peak flows in the rainy season. In the plains and Pantanal, however, the average annual flow peaks occur in the dry period. This is due to the basin's characteristics, which has an intricate drainage system, with large flood-prone areas that act as reservoirs.

Thus, the Paraguay River presents a typical regime of single mode tropical inundation in the portion where the Ladário station is located (Catella, 2001; Soares et al., 2008) or else, each year the river level in Ladário (MS), presents one single phase of ascent (growth), reaching the peak of flooding, and a single phase of descent (recession), not considering the little "bursts" that occur in the low water season (Galdino and Clarke, 1995, 1997).

The phase of rising waters is called inundation and the lowering of waters is called leaking. Transitions between periods are called floods, when the river reaches its peak level, and drought when it reaches minimum level. With those figures in hand it is possible to characterise a period as either dry or flooded in Pantanal (ANA, 2008).

In 2006, Ladário station registered a level of $5.40 \mathrm{~m}$, and it was considered by Soares et al. (2008) as the highest flood peak since 1997. According to the authors, in the same year, during the phase of drying up, the levels observed were above the historical average, and the minimum datum attained (2.16 $\mathrm{m}$ in 6 December 2006) was also the highest since 1992 .

However, in spite of the large volume of water hoarded up in the surface or underground reservoirs of the Pantanal in the floods of 2006 and 2007 (Soares et al., 2008), the Ladário station registered, during the outflow of 2007, one of the lowest minimum levels of the last 34 years, that is $88 \mathrm{~cm}$ on 3 November 2007.

In accordance with the classification by Galdino et al. (2002), the flood in the hydrologic period 2007-2008, 
as well as the floods of the two previous years, may be considered "normal", that is, when the maximum water level in Paraguay River ranges between 5.00 and $5.99 \mathrm{~m}$ in Ladário.

According to a bulletin from the National Water Agency (ANA, 2008), in early 2008 the pluviometric precipitations were above the historical average in practically the entire BAP.

Total rainfall in January and February exceeded the historical average in $40 \%$ and $60 \%$, respectively. The increased local rainfall contributed to a quick rise of the river water levels in the beginning of the flood period (end of 2007 and beginning of 2008).

Climate conditions on their own are not sufficient to explain the differences observed in the Paraguay River regime and some of its tributaries. The complexity of the hydrologic regime of the Paraguay River are related to the smooth declivity of the terrain comprised by the lowlands and marshlands in Mato Grosso (between 50 and $30 \mathrm{~cm} / \mathrm{km}$ in the east-west direction and 3 to $1.5 \mathrm{~cm} / \mathrm{km}$ from north to south). It is also owed to the area's extension, which remains periodically flooded, with a great volume of water. The river's sinuous course and the numerous geographic features outcropping in the flooded plains contribute to the sluggishness of water flows.

\section{References}

ADAMOLI, J., 1996. Previsão de médio prazo dos níveis do Rio Paraguai em Ladário, MS. In Anais do II Simpósio sobre Recursos Naturais e Sócio-Econômicos do Pantanal. Corumbá, MS: CPAP-EMBRAPA, UFMS. p. 59-72.

Agência Nacional de Águas - ANA, 2004. Strategic action program for the integrated management of the Pantanal and the Upper Paraguay River Basin. Brasília, DF: ANA/GEF/PNUMA/ OEA. 315 p.

-, 2008. Boletim de monitoramento da Bacia do Alto Paraguai. Brasília, DF: ANA. vol. 3, no. 3, 21 p. Available from: $<$ http://www.ana.gov.br/GestaoRecHidricos/UsosMultiplos/ BoletinsMonitoramento/AltoParaguai/Boletim_Monitoramento_ Alto_Paraguai_2008_03.pdf>. Access in: nov. 2009.

ALHO, CJR. and GONÇALVES, HC., 2005. Biodiversidade do Pantanal. Ecologia e conservação. Campo Grande-MS: Editora UNIDERP. $142 \mathrm{p}$.

CARVALHO, NO., 1986. Hidrologia da Bacia do Alto Paraguai. In Anais do I Simpósio sobre Recursos Naturais e Sócio-Econômicos do Pantanal. Brasília, DF: EMBRAPA. p. 43-50.

CATELLA, AC., 2001. A pesca no pantanal de Mato Grosso do Sul, Brasil: descrição, nível de exploração e manejo (1994-1999). Manaus: Universidade do Amazonas; Instituto Nacional de Pesquisas da Amazônia. Tese de doutorado em ciências biológicas, área de concentração, em biologia de água doce e pesca interior.

Estudo de Desenvolvimento Integrado da Bacia do Alto Paraguai - EDIBAP, 1979. Relatório da primeira fase: descrição física e recursos naturais. Brasília, DF: Superintendência do Desenvolvimento da Região Centro-Oeste.
GALDINO, S. and CLARKE, RT., 1995. Levantamento $e$ estatística descritiva dos níveis hidrométricos do rio Paraguai em Ladário, MS - Pantanal. Corumbá, MS: EMBRAPA-CPAP. 72 p. Documentos, 14

-, 1997. Probabilidade de ocorrência de cheia no rio Paraguai em Ladário, MS - Pantanal. Período 1900-1994. Corumbá, MS: EMBRAPA-CPAP. 58 p. Circular Técnica, 23.

GALDINO, S., VIEIRA, LM., OLIVEIRA, H. and CARDOSO, EL., 2002. Impactos da agropecuária nos planaltos sobre o regime hidrológico do Pantanal. Corumbá: EMBRAPACPAP. 6 p. Circular Técnica, 37. Available from: <http://www.cpap. embrapa.br/publicacoes/online/CT37.pdf>. Access in: nov. 2009.

HAMILTON, SK., SIPPEL, SJ. and MELACK, JM., 1996. Inundation patterns in the Pantanal wetland of South America determined from passive-microwave remote sensing. Archiv fur Hydrobiologie, vol. 137, no. 1, p. 1-23.

HAMILTON, SK., SIPPEL, SJ., CALHEIROS, DF. and MELACK, JM., 1997. An anoxic event and other biogeochemical effects of the Pantanal wetland on the Paraguay River. Limnology and Oceanography, vol. 42, no. 2, p. 257-272.

HAMILTON, SK., SOUZA, OC. and COUTINHO, ME., 1998. Dynamics of floodplain inundation in the alluvial fan of the taquari River (Pantanal, Brazil). Verhandlungender Internationale Vereinigung fur Theoretiche und Angewandtle Limnologie, vol. 26, p. 916-922.

Plano de Conservação da Bacia do Alto Paraguai - PCBAP, 1997a. Metodologia do plano de conservação para a Bacia do Alto Paraguai. Brasília: Ministério do Meio Ambiente, Programa Nacional do Meio Ambiente. vol. 1.

-, 1997b. Diagnóstico ambiental da Bacia do Alto Paraguai; t. 1 - Meio físico; t. 2 - Hidrossedimentologia; t.3 - Meio biótico; t. 4 - Sócio-economia de Mato Grosso; t. 5 - Sócio-economia de Mato Grosso do Sul; t. 6 - Aspectos hurídicos e institucionais de Mato Grosso; t. 7 - Aspectos jurídicos e institucionais de Mato Grosso do Sul. Brasília: Ministério do Meio Ambiente, Programa Nacional do Meio Ambiente. vol. 2.

-, 1997c. Análise integrada e prognóstico da Bacia do Alto Paraguai. Brasília: Ministério do Meio Ambiente, Programa Nacional do Meio Ambiente. vol. 3.

SÁ, LDA., SAMBATTI, SBM. and GALVÃO, GP., 1998. Ondeleta de Moelet aplicada ao estudo da variabilidade do nível do rio Paraguai em Ladário, MS. Pesquisa Agropecuária Brasileira, vol. 33, no. especial, p. 1775-1785.

SILVA, TC., 1984. Contribuição da geomorfologia para o conhecimento e valorização do Pantanal. In Anais I Simpósio sobre Recursos Naturais e Sócio Econômicos do Pantanal. Corumbá. p. 77-90.

SOARES, MTS., SORIANO, BMA., SANTOS, SA., ABREU, UGP., BERGIER, I. and PELLEGRIN, LA. 2008. Monitoramento do comportamento do rio Paraguai no Pantanal Sul-MatoGrossense - 2007/2008. Corumbá, MS: Embrapa Pantanal. 5 p. Comunicado Técnico, 72. Available from: <http://www.cpap. embrapa.br/publicacoes/download.php?arq_pdf=COT72>. Access in: 10 mar. 2008.

VALVERDE, O., 1972. Fundamentos geográficos do planejamento rural do município de Corumbá. Revista Brasileira de Geografia, vol. 34 , no. 1 , p. 49-144. 